J. Clin. Chem. Clin. Biochem.

Vol. 19,1981 , pp. 39-40

\title{
A Continuous Photometric Method for the Determination of Small Intestinal Invertase
}

\author{
By W. Hansen and D. Schreyer
}

\section{Medizinische Klinik der Technischen Universität München, Klinikum rechts der Isar}

(Received February 6/August 26, 1980)

Summary: An easy to perform, rapid and precise assay for invertase is introduced. In it enzyme activity is determined spectrophotometrically from a coupled enzymatic reaction.

\section{Ein kontinuierlicher spektrophotometrischer Test für die Dünndarminvertase}

Zusammenfassung: Ein einfacher, rasch durchführbarer und präziser Test für Invertase wird vorgestellt. In ihm wird die Enzymaktivität spektrophotometrisch anhand einer gekoppelten enzymatischen Reaktion gemessen.

\section{Introduction}

High activities of invertase ( $\beta$ - $D$-Fructofuranoside-fructohydrolase; EC 3.2.1.26) are found in the brush border of small intestinal mucosa. In diseases of the small intestine, invertase activity is reduced (1). Measurement of the enzyme is of value for the diagnosis and control of small bowel diseases as well as for physiological studies, but its widespread application has been hindered by the laborious methods of determination. In this paper a method based on the following equations will be presented: 1. sucrose $+\mathrm{H}_{2} \mathrm{O} \stackrel{\text { invertase }}{\longrightarrow}$ glucose + fructose

2. $\beta-D$-glucose $+\mathrm{NAD}^{+}$glucose dehydrogenase, $D$-glucono- $\delta$-lactone $+\mathrm{NADH}+\mathrm{H}^{+}$ Glucose dehydrogenase $(\beta-D$-Glucose: NAD 1-oxidoreductase, EC 1.1.1.47) is supplemented by mutarotase (Aldose-1-epimerase, EC 5.1.3.3) in order to increase the reaction speed. Originally equation (2.) was introduced for the determination of glucose (2). Invertase activity is measured from the generation of $\mathrm{NADH}$ which can be followed photometrically at $334 \mathrm{~nm}$.

\section{Methods}

Investigations were performed on human duodenal mucosa obtained during routine gastroduodenoscopy by forceps biopsy. All patients gave written, informed consent.

The biopsy particles were treated in the following way: excess moisture was removed by brief contact with filter paper. The samples were weighed on a microbalance and either refrigerated immediately at $-20^{\circ} \mathrm{C}$ or kept at $4{ }^{\circ} \mathrm{C}$ for subsequent determinations. For assay the specimens were homogenized by sonification for $60 \mathrm{~s}$ in distilled water at $4^{\circ} \mathrm{C}$. (Labsonic 1510, Braun Melsungen, Germany; setting at $60 \mathrm{~W}) .10 \mathrm{mg}$ of tissue required about $0.5 \mathrm{ml}$ water.

For practical purpose invertase was determined in a "reaction mixture" consisting of a phosphate buffer $0.13 \mathrm{~mol} / \mathrm{l}, \mathrm{pH} \mathrm{7.6}$, which contained $0.15 \mathrm{~mol} \mathrm{NaCl}, 26 \mathrm{kU}$ glucose dehydrogenase $0.55 \mathrm{kU}$ mutarotase, $0.117 \mathrm{~mol}$ sucrose and $0.0055 \mathrm{~mol} \mathrm{NAD}$ in $1000 \mathrm{ml}$. All reagents were analytical grade and obtained from E. Merck, Darmstadt, Germany. $0.5 \mathrm{ml}$ of this reaction mixture and $0.05 \mathrm{ml}$ of sample were added to microcuvettes. The reaction was followed in a photometer with recording attachments (Eppendorf Gerätebau, Hamburg, Germany). The temperature was set at $25^{\circ} \mathrm{C}$. Linearity was obtained after 1 min. Enzyme activity was calculated from the angle $\alpha$ of this line. For the blank value saline was added instead of sample. If necessary, correction for the blank value was made by subtracting the tg of both angles. Activity was calculated from the following formula:

Catalytic activity $=\operatorname{tg} \alpha \times \frac{V \times 1000 \times p}{v \times \epsilon \times 1 \times D}(U / 1)$

$(\mathrm{v}=$ sample volume $(0.05 \mathrm{ml}) ; 1=$ light path $(1 \mathrm{~cm})$;

$V=$ to tal volume $(0.5 \mathrm{ml}) ; \epsilon=$ absorption coefficient of $\mathrm{NADH}$; $\mathrm{p}=$ paper speed $(1 \mathrm{~cm} / \mathrm{min}) ; \mathrm{D}=$ diameter of the registration scale at absorbance $1.0(20 \mathrm{~cm})$ ).

The values of parameters are indicated in brackets. Invertase activity was calculated to be $89.4 \times \operatorname{tg} \alpha$. Reference determinations were also performed according to the standard procedure of Dahlqvist (3). It required one hour's incubation and a subsequent determination of free glucose using the glucose oxidase method.

Protein was determined according to Lowry et al. (4).

Statistical calculations and plots were performed on a HewlettPackard 9830 A computer. Results are expressed as the mean \pm standard deviation. The probability, $P$, was determined by Student's t-test. Correlation was calculated by the method of least squares.

\section{Results and Discussion}

About 1 min after the addition of sample to the reaction mixture the absorption increased continuously. The kinetics followed almost zero order thus reflecting invertase activity.

In order to establish optimal conditions of measurement the concentration of substrate was varied while using the 
same sample. Results from a typical experiment are given in figure 1. Saturation was reached at concentrations above $50 \mathrm{mmol} / 1$ sucrose, where changes in the concentration had little effect upon enzyme activity. The concentration of substrate for half maximal activity $\left(K_{\mathrm{m}}\right)$ was calculated according to Lineweaver-Burk. From 6 different experiments the value was $17 \pm 2.4 \mathrm{mmol} / \mathrm{l}$. This was the same order of magnitude as stated in the literature (5). For optimal measurement of invertase a sucrose concentration of $106 \mathrm{mmol} / 1$ was chosen.

The calibration curve was constructed by diluting a known invertase sample with saline. There was a linear relationship between the relative enzyme concentration and the tg of the angle $\alpha$ under the absorbance curve. Maximal $\alpha$ tested was $65^{\circ}$.

The quality of the assay was estimated by measuring 20 samples at the same time (coefficient of variation $4.1 \%$; $\overline{\mathrm{x}} \pm \mathrm{s}=54.5 \pm 2.26 \mathrm{U} / \mathrm{l}$ ), and by determining 10 samples on different days with different reaction mixtures (coefficient of variation of $4.7 \% ; \bar{x} \pm s=29.1 \pm 1.37 \mathrm{U} / 1)$.

The correlation with another method was studied in 66 different samples (fig. 2). They were determined by the conventional assay of Dahlqvist (3). The results obtained by the conventional method were higher by a factor of about 1.5. The correlation, however, was excellent $(r=$ $0.981, \mathrm{p}<0.0001)$. An explanation for the lower enzyme activities in the new assay may be seen in the lower temperature of reaction $\left(25^{\circ} \mathrm{C}\right.$ vs. $\left.37^{\circ} \mathrm{C}\right)$. Also measurements are not carried out at optimal $\mathrm{pH}$. Usually 1 biopsy particle weighing 5-7 mg was enough for the determination of invertase activity and protein concentration.

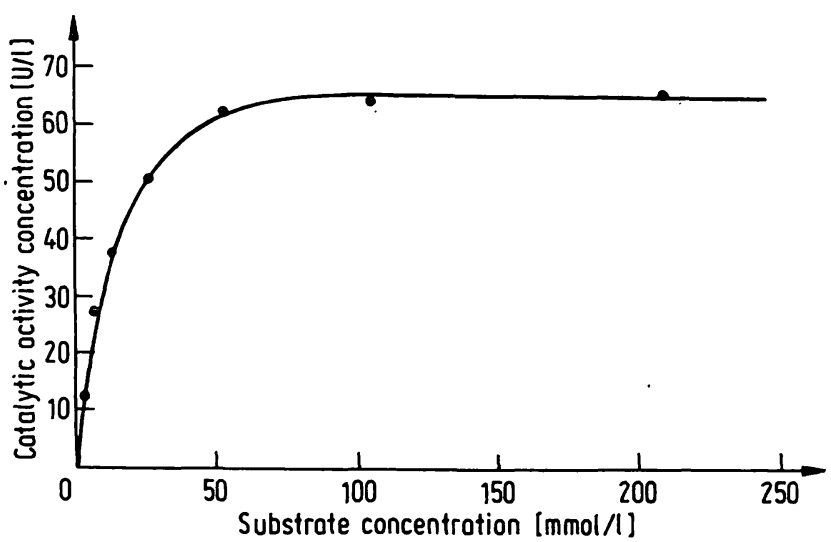

Fig. 1. Relationship between substrate (sucrose) concentration and catalytic activity concentration of invertase. Determinations were done in the same sample of homogenized duodenal mucosa. In this experiment $K_{\mathrm{m}}$ was $16 \mathrm{mmol} / \mathrm{l}$.

\section{References}

1. Sheehy, T. W. \& Anderson, P. R. (1965) Lancet II, 1-3.

2. Banauch, D., Brümmer, W., Ebeling, W., Metz, H., Rindfrey, H. Lang, H., Leybold, K. \& Rick, W. (1975) Z. Klin. Chem. Klin. Biochem. 13, 101-107.

3. Dahlqvist, A. (1970) in Methoden der enzymatischen Analyse (Bergmeyer, H. U. ed.), Vol. I, p. 877-884, Verlag Chemie, Weinheim, New York, 2nd edition.

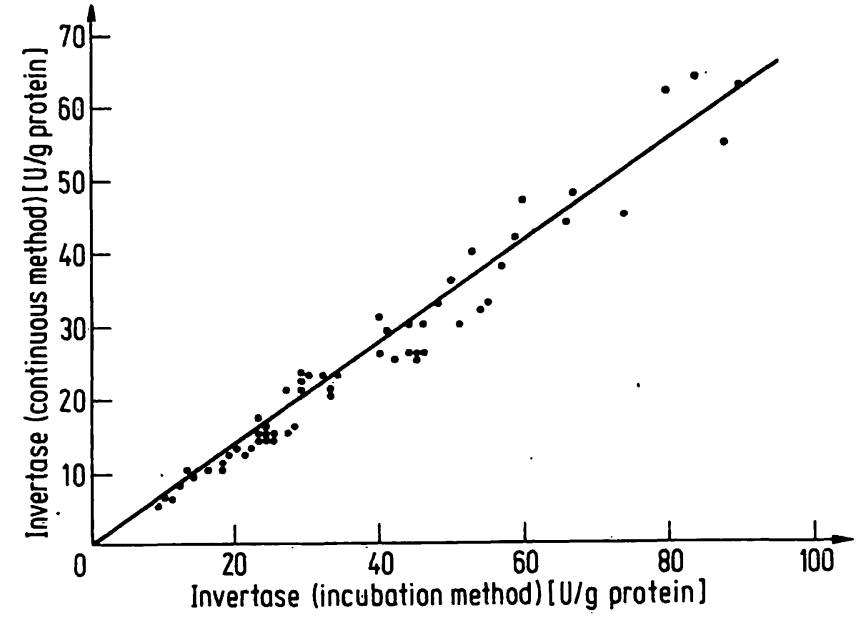

Fig. 2. Correlation between a conventional invertase assay (abscissa) and the new continuous assay (ordinate). The results obtained by the new method were lower by a factor of approximately 0.667 . The correlation curve followed the function $y=-1.59+0.71 \mathrm{x}$. The coefficient of correlation $\mathrm{r}$ was $0.981(\mathrm{p}<0.0001)$.

The continuous spectrophotometric test introduced here obviously meets the requirements for a reliable assay of invertase. Its main advantage may be seen in the fact that it can be performed much faster and easier than conventional tests. Using a semiautomatic unit 12 samples could be measured within $30 \mathrm{~min}$. The glucose dehydrogenase/mutarotase reaction used here is rapid. This enables precise measurements of invertase even at high enzyme activities. From a theoretical standpoint the assay should be able to measure other disacharidases that yield glucose, e.g. lactase ( $\beta-D$-Galactoside galactohydrolase, EC 3.2.1.23) by applying the proper substrate. However, we found this was impossible for lactase, because the commercially available glucose dehydrogenase preparation contained lactase activity.

The invertase reaction requires sodium ions (6). Therefore $\mathrm{NaCl}$ was added to the reaction mixture. The test will be disturbed by sample glucose concentrations higher than $0.3 \mathrm{mmol} / \mathrm{l}$. Under normal circumstances mucosal homogenates will almost be free of glucose. However, determinations in samples containing glucose, e.g. honey, will in some instances require prior dialysis against water.

\section{Acknowledgements}

This work contains parts of the doctoral thesis of $D$. Schreyer. It was supported by Deutsche Forschungsgemeinschaft (Ha 596/5). Dr. M. Lentze, Kinderklinik der Universität München, gave valuable advice.
4. Lowry, O. H., Rosebrough, N. J., Farr, A. L. \& Randall, R. I. (1951) J. biol. Chem. 193, 265-275.

5. Auricchio, S., Rubino, A., Tosi, R., Semenza, G., Landolt, M., Kistler, H. \& Prader, A. (1963) Enzymol. Biol. Clin. 3, 193-208.

6. Semenza, G., Tösi, R., Valloton-Delachaux, M. C., \& Mülhaupt, E. (1964) Biochim. Biophys. Acta 89, 109-116. 